\title{
Collaborative Research In Service Science: Quality And Innovation
}

Roberta S. Russell, Virginia Polytechnic Institute and State University, USA

\begin{abstract}
The unprecedented shift in customer, corporate and societal demand for services and the management of corresponding resources has created a critical need for research, education, and outreach in service systems. Universities worldwide are addressing this need through the establishment of collaborative research centers, such as the Center for Services Science, Quality and Innovation (SSQI) at Virginia Tech. This paper discusses service science as a promising field of research and suggests opportunities for collaboration across disciplines, institutions and cultures.
\end{abstract}

Keywords: service science, quality, innovation, collaborative research

\section{INTRODUCTION}

$\mathrm{n}$ the U.S., services account for $80 \%$ of the labor force, $90 \%$ of job growth, and $77 \%$ of GDP. Globally,
services account for over $60 \%$ of the economies of Brazil, Russia, Japan and Germany, and the service
sector is growing rapidly in the emerging economies of India and China. Without exception, services are now a larger percentage of GDP than manufacturing in every nation for which the World Bank maintains statistics (Metters, 2007). However, in academia, services research comprises less than $10 \%$ of journal publications in the fields of engineering and operations management. The same imbalance is seen in college curricula, with few courses on service operations, service management or services marketing.

The need for services research, education and innovation has been well-documented [Spohrer (2008), Demirkan (2008), University of Cambridge (2008)]. However, three areas deserve additional comment: (1) the importance of a service-dominant logic, (2) the emergence of services computing, and (3) the imperative of service quality and innovation to address major societal problems.

Service Dominant Logic. The impact of supporting services on product success has turned many product-producing companies into service providers. A fitting example is IBM who went from a producer of computer hardware to a producer of software to a provider of global business services. Apple's IPOD would not be as successful without the launch of ITunes. Equipment manufacturers receive more revenue from service contracts than from sales of the product. Returning customers may be influenced more by the customer service they receive after a sale than by the product itself. Service Dominant Logic (Lusch, 2008) puts service at the forefront of customer interaction. Rather than designing a car for sale (or even for a particular customer), companies would design and sell the service of transportation. This puts the onus of design on the customer experience and leads to better designs of physical products. The matching of firm capabilities with customer needs requires an ongoing conversation between provider and customer that builds a relationship for determining quality standards, co-creating innovative services, and increasing customer loyalty for a sustainable competitive advantage. Converting product-centered companies to service-centered companies (called servitization) may not be an easy transition. Designers are often absorbed with new technologies and their own version of what a product should be, to the detriment of the customer's experience with the product. Interestingly, the outsourcing of manufacturing has created the "service" of supply chain management which requires a different skill set of coordination and collaboration that is useful in other areas of business. It is not surprising that service dominant logic originated in the field of services marketing rather than operations, and that services marketing is a growing and vibrant field of study. 
Service Computing. Nowhere has the emergence of a service dominant logic been more transformative than in service computing. Service computing has prompted a new level of understanding of customer requirements and design theory. Rather than selling a software product that is run and maintained by the purchaser, software as a service (SaaS) allows users to select which services are needed and run them from the vendor's site. The vendor maintains the server, upgrades the software, and secures the data. The user selects only those services that are needed and can change, add, or delete services at any time. Software vendors are faced with decoupling their software, modularizing their services and re-combining them in different ways at a customer's request. Personnel are also greatly affected by this change. Software engineers must change the architecture of design (aptly called serviceoriented architecture or SOA) and IT consultants must be able to understand and communicate user needs with both vendor and user. This requires another level of training beyond technical skills, e.g., people skills, process skills, and a strong service orientation (Demirkan, 2008).

Service Imperatives. Major societal problems, such as education, healthcare, disaster relief, and government services, depend on complex customer-focused processes and benefit significantly from an innovative and interdisciplinary approach to their study and analysis. For example, an OR researcher may view disaster management in terms of critical infrastructure, efficient deployment of resources, and recovery time; whereas, a service-oriented researcher would consider those factors and in addition, the network of people, capabilities and connections that would impede or accelerate recovery (Zobel, 2009). The need for communication with clients to share knowledge about their domain and to guide the development of an acceptable and feasible disaster recovery plan reflects one of the precepts of effective service systems, the co-creation of value.

One of the advantages of a services approach is getting to know the customer, and that entails knowing when to standardize a service and when to remain flexible and responsive to particular customer needs. The identification of expressed and unexpressed needs is the purview of social sciences, such as psychology and anthropology, married with a strong design orientation. Marketing researchers bring skills in focus groups, customer relationship management, and customer surveys. Information technology applies business intelligence tools such as data mining, text mining, and pattern recognition software to the vast amounts of data collected. Collaboration of these disciplines generates new ideas and leads to richer solutions to services problems, as well as more innovative service designs. Approaching service design and delivery in a systematic way with a diverse set of skills and backgrounds is the basis for the new field of study called services science.

\section{SERVICE AS A SCIENCE}

The concept of "service science" was developed in 2002 by UC Berkeley Professor Henry Chesbrough as he worked with IBM's Almaden Research Center to study services as social engineering systems. The term was used first publically in the "Innovate America" report of The Council on Competitiveness, chaired by IBM CEO, Sam Palmisano (Council, 2005). The America COMPETES Act (2007) was a direct result of the Innovate America study. COMPETES (Creating Opportunities to Meaningfully Promote Excellence in Technology, Education, and Science) included a definition of services science and a mandate to increase emphasis on services research.

The field of services is very broad and somewhat ill-defined, and to some the words "service" and "science" do not seem compatible. Reluctance of professors in technical fields to engage in services research can be attributed in part to the misconceptions that (1) services are less complex than manufacturing with little or no need for quantitative analysis; (2) services are not as high-tech or scalable as manufacturing with their emphasis on human interaction (i.e., soft issues); and (3) services contain too much variability to be efficiently managed or modeled (Metters, 2007). For other researchers and practitioners, viewing service as a science means putting less emphasis on individuals, people skills, and the human side of services. This, of course, was not the intention when the phrase was coined. It is the fact that people, i.e., both customers and service providers, are involved in cocreating the service and the service experience that prompts a scientific approach to service design. The essence of science is its reproducibility, regardless of participants, and its capacity for producing results with a high degree of future predictability. Thus, the role of "science" in co-production is to quantifiably forecast future value and risk for both parties (Abe, 2005). By systematically developing, delivering, managing and measuring services, the quality of service can be scaled and sustained in different environments. This enhanced quality of service will, in turn, accelerate service innovation, as less time and effort is expended replicating service performance. This was the 
original goal of service science, to respond to a critical need for innovation, as detailed in the Innovate America report (Kramer, 2005).

\section{SERVICES RESEARCH}

Services research, both in terms of academic journals and funded research, is important to economic viability, global trade, and advances in service innovation. While the National Science Foundation has funded services research in the past through existing social sciences and information sciences directorates, a program specifically directed at services was established (albeit housed under Civil, Mechanical and Manufacturing Innovation) as Service Enterprise Engineering. Table 1 lists the directorates, divisions, clusters and programs related to services research within NSF. Recovery Act funding for healthcare IT, education, green initiatives and government cost containment have opened up new opportunities for applying the interdisciplinary approach of service science to major societal problems. Health services research is funded by the agency for Healthcare Research and Quality (AHRQ) of the National Institute of Health (NIH), as well as from the Department of Veteran Affairs. The Departments of Defense and Energy also provide service-related funding.

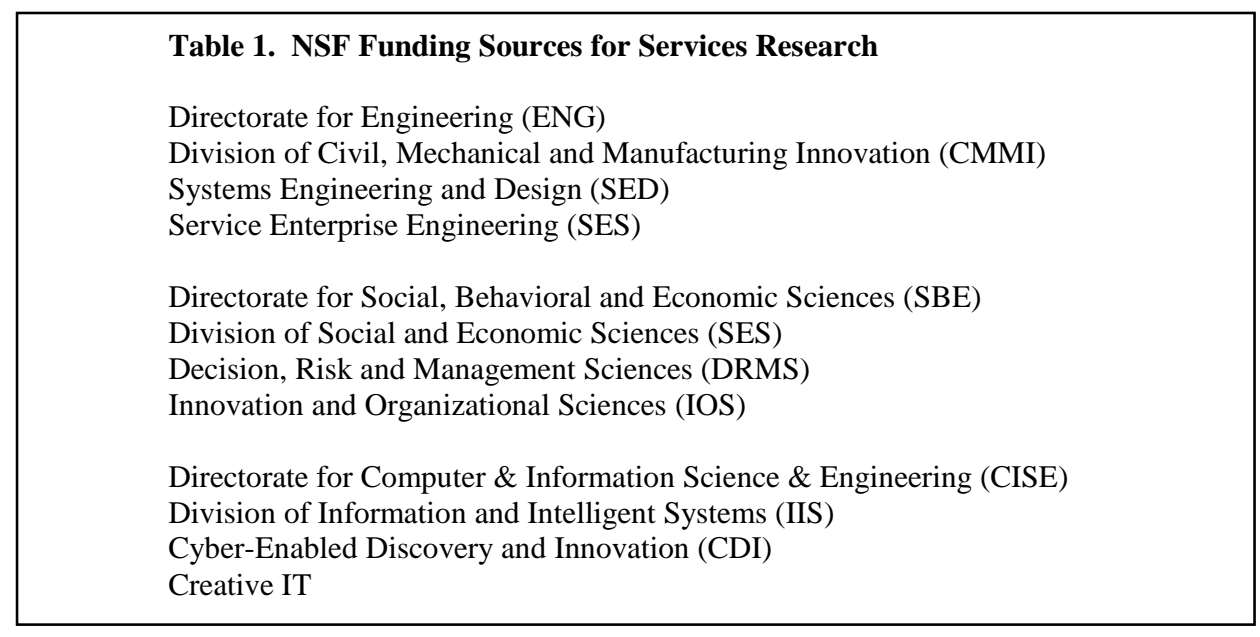

Table 2 lists fourteen university research centers located in North America, Asia and Europe that focus on services. The research centers at Maryland, Arizona State, Wharton, RPI and Karlstad, Sweden have been in existence for some time. The remaining nine centers were formed within the past five years in response to renewed interest and funding for services research. The centers are housed in different university departments and colleges, ranging from marketing, information systems, and operations management, to industrial engineering, computer science and social sciences. These centers provide opportunities not only for cross-disciplinary research, but crosscultural research. For example, ISSER at the University of Puerto Rico is sponsoring an NSF-funded research consortium to study cultural differences in service systems.

The recent resurgence of interest in services has also spawned a multitude of academic journals in service science and management. Table 3 lists sixteen journals specifically related to services. There are, of course, other journals that publish services research, such as Journal of Operations Management, Production and Operations Management, Decision Sciences, Management Science, Operations Research and Naval Logistics Quarterly, but they do so sparingly. 
Table 2. Selected Research Centers in Services

\begin{tabular}{|c|c|}
\hline Research Center & $\begin{array}{c}\text { Institution / Webpage } \\
\text { Conferences / Journals / Surveys }\end{array}$ \\
\hline Center for Excellence in Service & $\begin{array}{l}\text { University of Maryland http://www.rhsmith.umd.edu/ces/ } \\
\text { Frontiers in Services Conference; } \\
\text { Journal of Service Research; } \\
\text { National Technology Readiness Survey; } \\
\text { Small Business Success Index }\end{array}$ \\
\hline Center for Services Leadership & $\begin{array}{l}\text { W.P. Carey School of Business, Arizona State University } \\
\text { http://wpcarey.asu.edu/csl/ } \\
\text { Compete Through Service Symposium; } \\
\text { Services Leadership Institute }\end{array}$ \\
\hline $\begin{array}{l}\text { Center for Services Research and Education } \\
\text { (CSRE) }\end{array}$ & $\begin{array}{l}\text { Rensselaer Polytechnic Institute (RPI) } \\
\text { http://www.dses.rpi.edu/csre/ }\end{array}$ \\
\hline $\begin{array}{l}\text { Center for Services Science, Quality and Innovation } \\
\text { (SSQI) }\end{array}$ & $\begin{array}{l}\text { Pamplin College of Business, Virginia Tech } \\
\text { www.ssqi.pamplin.vt.edu }\end{array}$ \\
\hline Centre for Service Research (CSR) & $\begin{array}{l}\text { Manchester Business School } \\
\text { University of Manchester, UK } \\
\text { http://www.mbs.ac.uk/research/csr/ }\end{array}$ \\
\hline $\begin{array}{l}\text { Complex Services Innovation Research Network } \\
\text { (CSIRN) }\end{array}$ & $\begin{array}{l}\text { Faculty of Law, Business \& Social Sciences } \\
\text { University of Glasgow, UK } \\
\text { http://www.gla.ac.uk/departments/csirn }\end{array}$ \\
\hline $\begin{array}{l}\text { International Service Systems Engineering } \\
\text { Research Lab (ISSER) }\end{array}$ & $\begin{array}{l}\text { University of Puerto Rico at Mayaguez } \\
\text { http://ininweb.uprm.edu/isser }\end{array}$ \\
\hline IT Services Qualification Center (ITSQC) & $\begin{array}{l}\text { Carnegie Mellon } \\
\text { http://www.gla.ac.uk/departments/csirn }\end{array}$ \\
\hline Karlsruhe Service Research Institute & $\begin{array}{l}\text { Karlsruhe Institute of Technology, Germany } \\
\text { http://www.ksri.uni-karlsruhe.de/ }\end{array}$ \\
\hline $\begin{array}{l}\text { Service Research and Innovation Community } \\
\text { (SRIC) }\end{array}$ & $\begin{array}{l}\text { Consortium of Businesses and Universities } \\
\text { http://forums.thesrii.org/srii }\end{array}$ \\
\hline $\begin{array}{l}\text { The Fishman-Davis Center for Service and } \\
\text { Operations Management }\end{array}$ & $\begin{array}{l}\text { The Wharton School, University of Pennsylvania } \\
\text { http://grace.wharton.upenn.edu/fd/ } \\
\text { Consortium for Operational Excellence in Retailing (COER); } \\
\text { Service Supply Chain Strategy Forum }\end{array}$ \\
\hline The Research Center for Modern Services & $\begin{array}{l}\text { School of Software and Microelectronics, } \\
\text { Peking University; Beijing, China } \\
\text { http://www.ss.pku.edu.cn/en/departments.html } \\
\text { (click on Department of Service Science) }\end{array}$ \\
\hline The Service Research Center (CTF) & $\begin{array}{l}\text { Karlstad University, Sweden } \\
\text { http://www.ctf.kau.se/ } \\
\text { Journal of Service Management }\end{array}$ \\
\hline The Swiss Institute of Service Science (SISS) & $\begin{array}{l}\text { University of Applied Sciences } \\
\text { (Zurich, West Switzerland, North-West Switzerland) } \\
\text { http://crag.hesge.ch/service-science/ }\end{array}$ \\
\hline
\end{tabular}

\section{THE CENTER FOR SERVICES SCIENCE, QUALITY AND INNOVATION (SSQI)}

The Center for Services Science, Quality and Innovation (SSQI) was established within the Pamplin College of Business at Virginia Tech to coordinate multidisciplinary research, instruction and outreach activities for the design, improvement and innovation of service systems. SSQI promotes a scientific approach to service design that combines an understanding of business processes, customer needs and emerging technologies (see Figure 1). It seeks to develop measures of effectiveness for service systems and improve those systems through quality initiatives and innovation. The center structure was chosen as a vehicle for encouraging inter-disciplinary research with academic units for whom funded research is a priority. The center also provides focus for colleagues from diverse fields of study and helps to validate the relevance and applicability of their joint research. The center's mission reflects that of the university in three areas - research, outreach and education. 
Table 3. Academic Journals specifically related to Services

\begin{tabular}{|c|c|}
\hline Journal & Publisher/ Webpage \\
\hline e-Service Journal & $\begin{array}{l}\text { Indiana University Press } \\
\text { www.e-sj.org/ }\end{array}$ \\
\hline $\begin{array}{l}\text { International Journal of Service Science, } \\
\text { Management, Engineering, and Technology } \\
\text { (IJSSMET) }\end{array}$ & $\begin{array}{l}\text { IGI Global } \\
\text { http://www.igi-global.com/journals/details.asp?ID=32918 }\end{array}$ \\
\hline $\begin{array}{l}\text { International Journal of Services and } \\
\text { Operations Management (IJSOM) }\end{array}$ & $\begin{array}{l}\text { Inderscience } \\
\text { www.inderscience.com/ijsom }\end{array}$ \\
\hline $\begin{array}{l}\text { International Journal of Services Operations } \\
\text { and Informatics (IJSOI) }\end{array}$ & $\begin{array}{l}\text { Inderscience } \\
\text { www.inderscience.com/ijsoi }\end{array}$ \\
\hline $\begin{array}{l}\text { International Journal of Services Sciences } \\
\text { (IJSSCI) }\end{array}$ & $\begin{array}{l}\text { Inderscience } \\
\underline{w w w . i n d e r s c i e n c e . c o m / i j s s c i / ~}\end{array}$ \\
\hline $\begin{array}{l}\text { International Journal of Services Technology } \\
\text { and Management (IJSTM) }\end{array}$ & $\begin{array}{l}\text { Inderscience } \\
\text { www.inderscience.com/ijstm }\end{array}$ \\
\hline Journal of Service Management (JOSM) & $\begin{array}{l}\text { Emerald } \\
\text { http://info.emeraldinsight.com/products/journals/journals.htm?id=josm }\end{array}$ \\
\hline Journal of Service Research (JSR) & $\begin{array}{l}\text { Sage } \\
\text { http://jsr.sagepub.com/ }\end{array}$ \\
\hline Journal of Service Science (JSS) & $\begin{array}{l}\text { Clute Institute } \\
\text { http://www.cluteinstitute-onlinejournals.com }\end{array}$ \\
\hline $\begin{array}{l}\text { Journal of Service Science and Management } \\
\text { (JSSM) }\end{array}$ & $\begin{array}{l}\text { Scientific Research } \\
\text { http://www.scirp.org/journal/jssm }\end{array}$ \\
\hline Journal of Services Marketing (JSM) & $\begin{array}{l}\text { Emerald } \\
\text { http://info.emeraldinsight.com/products/journals/journals.htm?id=jsm }\end{array}$ \\
\hline Managing Service Quality & $\begin{array}{l}\text { Emerald } \\
\text { http://info.emeraldinsight.com/products/journals/journals.htm?id=msq }\end{array}$ \\
\hline $\begin{array}{l}\text { Manufacturing and Service Operations } \\
\text { Management (MSOM) }\end{array}$ & $\begin{array}{l}\text { INFORMS } \\
\text { http://msom.journal.informs.org/ }\end{array}$ \\
\hline Service Business & $\begin{array}{l}\text { Springer } \\
\text { http://www.uv.es/sb/ }\end{array}$ \\
\hline Service Science & $\begin{array}{l}\text { Services Science Global } \\
\text { http://www.sersci.com/ServiceScience/ }\end{array}$ \\
\hline The Services Industry Journal & $\begin{array}{l}\text { Taylor \& Francis } \\
\text { http://www.tandf.co.uk/journals/titles/02642069.asp }\end{array}$ \\
\hline
\end{tabular}

Research. Center faculty affiliates come from five colleges and ten departments within the university. The multidisciplinary nature of center participants results in research focused on a broad range of services related topics. The center's research agenda encompasses the fields of disaster recovery, healthcare, e-government, IT privacy and security, hospitality services, and financial services. SSQI research capabilities include knowledge management, data mining, visualization, and service quality, delivery, outsourcing, and design. The center supports and conducts research that has practical relevance and value for the business community and theoretical significance for the academic community.

The response from researchers across campus was immediate when the service center was announced. Involvement from various departments within business and historically affiliated departments such as industrial engineering, statistics, and computer science was expected. Participation by faculty from education, psychology, architecture, agriculture, law, bioinformatics, geography, and science and technology was unexpected but welcomed.

In order to encourage collaboration and hold the interest of this diverse group, the center sets meeting agendas on emerging technologies (such as data mining or geographic information systems), customer needs (such as tourism management, healthcare, or privacy and security), and processes (such as designing servicescapes, determining service capacity, or analyzing neurological data). From these sessions, faculty pursue joint research 
projects and, if needed, seek help from the center in grant applications. Project requests also come from industry. A yearly wrap-up of activities celebrates success and helps to plan agenda items for subsequent meetings and projects.

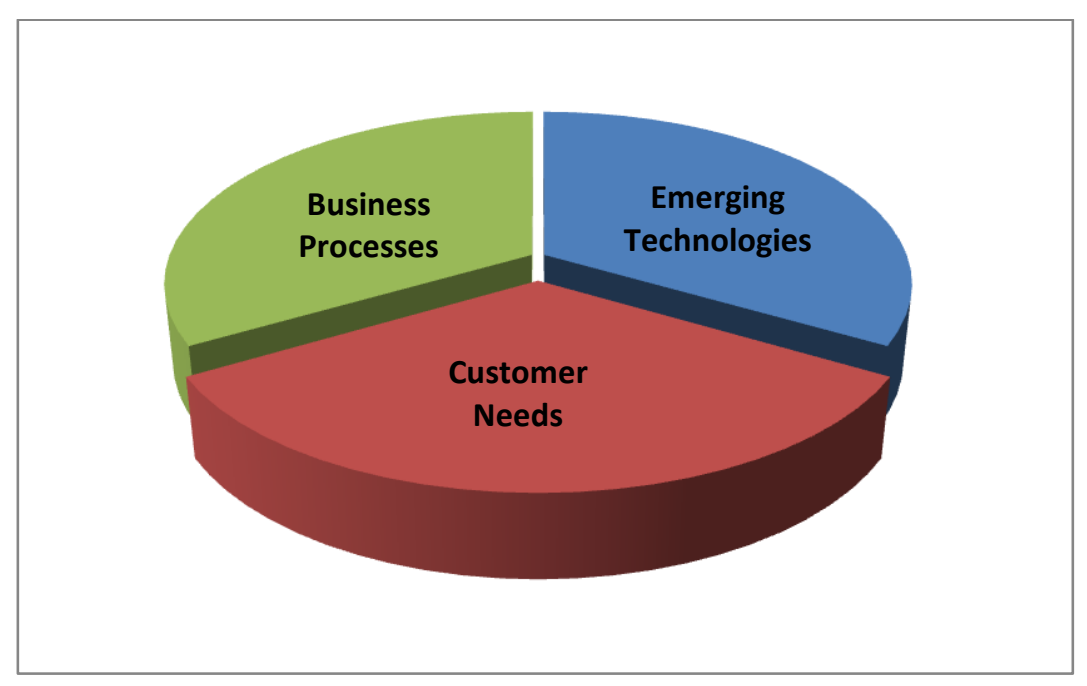

Figure 1. A Scientific Approach to Service Design

Outreach. Center members regularly make presentations on various aspects of service quality and innovation, both within the university community and to academics, organizations, and corporations at the regional, national, and international levels. Members are also available for customized seminars and services training.

As interest in center activities grew within the university administration and local industry, the center was asked to conduct training in "creating a service culture" and "excellence in customer service". We were able to apply our customer/process/technology approach in the training sessions, as in at least two cases, what was perceived as a "customer service" problem was actually a "process" problem, alleviated by technology and process redesign,.

Education. The Center promotes a curriculum that enhances graduate and undergraduate education in service systems, and brings together academia and industry to share the newest developments in services. Courses taught by members of the center provide a service focus to a diverse population of students from engineering, IT, and business disciplines. Students involved in center projects will emerge as potential employees who are both technically savvy and customer focused. Corporations, businesses and government alike need experienced workers who can simultaneously expand innovation and productivity; and can work successfully with both people and technology.

The educational goals of the center were accomplished by incorporating service topics, cases and discussions in existing courses, expanding electives for students in various majors to include service-related courses, bringing in guest speakers (including faculty affiliates and industry contacts from center activities), and creating opportunities for students to participate in center projects. Budget constraints prohibited the creation of new courses, majors or concentrations, as well as hosting conferences or planning workshops for colleagues from other universities. Nevertheless, as faculty have proceeded to give presentations at conferences and events, joint research projects across universities have become more common.

\section{SUMMARY}

In this paper, we briefly summarized the need for and movement toward service science in academia and industry, and presented a list of contacts for both research funding and publications. We then described the establishment of a research center in service science, quality and innovation. As a closing note, we relate an experience in collaborative research at the center. 
One of the design exercises undertaken by a graduate student from the center involved envisioning a new airport facility. How would an airport designed from scratch differ from existing airports that are retrofitted to handle safety and security? During one of the discussions, colleagues from a school of design shared their view that "efficiency has sucked the life out of human interaction." Only when we began discussing the flow of customers through the system and the "beauty" of seamless interactions did we find common ground. There is value in collaboration among diverse colleagues, but the way is not always easy.

We learned to balance the push for services science (it's not all about engineering) and open our minds to other ways of working, melding together concern for customer needs with business processes and emerging technologies. The experience proved especially useful for two members of our group from different colleges who received a grant "to promote interdisciplinary collaboration and innovation through network tools."

\section{AUTHOR INFORMATION}

Roberta Russell is a Professor of Business Information Technology in the Pamplin College of Business at Virginia Tech and Director of the Center for Services Science, Quality and Innovation (SSQI). Dr. Russell conducts research in operations management, service operations, quality management and supply chains. She has published in Decision Sciences, IIE Transactions, Journal of Operations Management and others. She is also co-author of Operations Management: Creating Value Along the Supply Chain published by Wiley. Dr. Russell is a member of DSI, APICS, ASQ, and IIE. She is a certified fellow (CFPIM) of APICS and a supply chain management professional (CSCP).

\section{REFERENCES}

1. Abe, Tadahiko (2005). What is Service Science? Research Report No. 246. Tokyo: Fujitsu Research Center.

2. $\quad$ America Competes Act (2007), Public Law 110-69. Washington, DC: GPO. Section 1105.

3. Council on Competitiveness (2005). Innovate America. National Innovation Initiative Summit and Report.

4. Demirkan, H., R. Kauffman, J. Vaughan, H. Fill, D. Karagiannis, \& P. Maglio (2008). Service-oriented technology and mangement: Perspectives on research and practice for the coming decade. Electronic Commerce Research and Applications. 7(4). 356-476.

5. Kramer, R., Kirby, J., Bower, J., Rayport, J., Bonabeau, E., Martin, R., et al. (2005). Breakthrough Ideas for 2005. Harvard Business Review, 83(2), 17-54.

6. Lusch, R., S. Vargo, \& G Wessels ( 2008). Toward a conceptual foundation for service science: Contributions from service-dominant logic. IBM Systems Journal, 47(1), 5-14.

7. Metters, R. and A. Marucheck (2007). Service Management-Academic Issues and Scholarly Reflections from Operations Management Researchers. Decision Sciences. 38(2), 195-215.

8. Spohrer, J. and P. Maglio (2008). The Emergence of Service Science: Toward Systematic Service Innovations to Accelerate Co-Creation of Value. Production and Operations Management, 17(3), 238-246.

9. University of Cambridge IfM and IBM (2008). Succeeding through service innovation: A service perspective for education, research, business and government. Cambridge, United Kingdom: University of Cambridge Institute for Manufacturing.

10. Zobel, C.W. ,J.R. Martin, II, and C.G. Olgun (2009). Disaster Risk Management for Critical Infrastructure: A Services-Based Viewpoint. International Journal of Services Sciences. Special Issue on Disaster Operations Management, in press. 


\section{NOTES}

